\title{
The Georgian Military Road
}

\section{Colonel C. E. De La Poer Beresford}

To cite this article: Colonel C. E. De La Poer Beresford (1907) The Georgian Military Road, Royal United Services Institution. Journal, 51:358, 1528-1531, DOI: $10.1080 / 03071840709418782$

To link to this article: http://dx.doi.org/10.1080/03071840709418782

$$
\text { 曲 Published online: } 11 \text { Sep } 2009 .
$$

Submit your article to this journal $\pi$

LII Article views: 4

Q View related articles $₫$ 


\title{
THE GEORGIAN MILITARY ROAD.
}

\author{
By Colonel C. E. DE LA POER BERESFORD \\ (late Milittry Attaché at St. Petersburg).
}

TIFLIS boasts of two good hotels and numerous siukhans or serâis. The latter form interesting points of observation for the artist, but the European traveller is not educated up to their ways. At the Hôtel de Londres, near the Vorontzoff bridge, or the Orient (pronounced Ariant), opposite the baroque Moorish Cathedral, he will find cleanliness and comfort, absent as a rule from provincial hotels in Russia. But of towns in the Caucasus, quaint and curious though they be, I do not care to speak. The country is as beautiful as any one can desire, and is as yet unspoilt bv the globetrotter or advertiser. Through its recesses the Russian engineers have driven the finest mountain road in the world. The Spliigen, St. Gothard, Cenis, are insignificant in comparison. It is called the Voennoe Grûzinskaya Doròga, or Georgian Military Road.

Most travellers declare that this famous pass should be traversed from north to south, i.e., from Vladikàvkas to Tiflis, from Europe into Asia. Coming from the interminable flatness of Russia the mighty mountains doubtless fill the mind with an indescribable joy. If only what is seen were described, the vublic would not be deceived by the accounts written of foreign lande. In Vol. VI., p. 40 of the English translation of M. Elisée Reclus's (as a rule so accurate) Geographie Universelle it is stated: "Although with a greater mean elevation than those of the Alps, the Caucrsian peaks are far less covered with snow and ice. . . . . The absenco of snow produces a corresponding scarcity of glaciers." This shows the danger of obtaining information at second hand, for every word is incorrect in this extract, save that as to the mean elevation of the range. More astounding still is it to read, in the 1877 edition of Keith Johnston's Dictionary of Geography: "The mountains of the Caucasus are either flat or cupshaped." The writer evidently had not seen the glorious panorama of snow-covered summits that unrolls itself from Kutais to the north of Gori and Krspi.

The only way to see the Georgian pass in comfort is to hire a post-chaise and four horses at the Government post establishment, at the end of Golovinsky Street, in Tiflis. The price for the journey to Vladikàvkas is about £5, including the road tax. Tips of sixpence at each of the twenty posting stations add another half-sovereign to the cost. As the distance is 201 versts, say 114 English miles, and that at the steep places six horses are provided, the fare is not excessive. The journey had best be broken at Mléti. For the first ten miles of the way the scenery is comparatively uninteresting. At Mtskhet, the ancient capital of the Georgian kings, a poor village at thé junction of the Aràgua and Kùra, the mountain road commences. The ancient castle of Harmotsica (in Georgian Arma-Tsiké, which 
means Ormuzd), now a mass of ruins, recalls the very finest corners of the Rhine. From here to Dushèt the road gradually ascenc's through an agricultural country. Far to the east is the magnificent wooded Kakhétia. Dushèt and its environs are at present in a very perturbed state, the landlords can get no rents, and the peasantry are in armed revolt. The next stage is a short one, but extremely interesting. The Caucasus mountain chain stretches for over 600 miles, a mass of limestone peaks buttressed by shale, through which the igneous upheaval pierces only twice, 16,000 feet.above sea level, at. Elbruz and Kasbek. All the other mountains, many of which are higher than Mt. Blanc, are below these basalt giants and of aqueous formation. But so vast has been the contortion produced by volcanic action, that the strata are twisted and turned into every conceivable formation. At times it is almost impossible to believe that these rocks are formed by the agency of water. The outlines of the mountains, far from being "flat or cup-shaped," are varied, angular, peaked, pointed, almost amorphous. There are the sierra or saw of the Spaniards, the mamelons of Elbrìz, the sugarloaf of Tetnuld, the twin cones of Ushba, the indented wall of Adai-Kokii; and the basalt peak of Kasbek to which we shall come presently. The glacier field is enormous. Beside the Kara-gom, the $M$ er de Glace is an ice-pond. The military road crosses, it does not intersect this vast chain. At Ananûr, about fifteen miles from Dushèt, it enters the mountains.

Ananûr is a tiny town perchod on a little hill separating the valleys of the Aràgua and another stream. From these rivers unsophisticated trout rise greedily at any fly. The church is a splendid cruciform structure, whose dentelated ornamentation and round arches suggest an origin of the X. or XI. century. The tower is many sided so as to appear almost cylindrical. Its conical roof, like that of the rest of the edifice, is of glaring tin, that much distresses the eye. The old walls and those of the castle are built of huge limestone blocks. Above the village the mountains rise steeply. The whole of the next stage is in a narrow valley seldom lit by the sun's rays. The sides of the hills are clothed with luxurious vegetation. The inhabitants are Georgians, living in comfortable cottages and dressed, as a rule, in the flowing tcherkeska or flowing skirted coat of rough wool, with cartridge cases sown across the breasts. Pàssanûr is a delightful village crowded into the bed of the stream by the descending slopes. It lies at about 3,000 feet above the sea. In its market place when last I passed through it was chained a little grey bear that was offered to me for 10 roubles. I thought that cheap; as he was, he might prove an awkward travelling companion, so declined the offer.

We enter now the zone of schists and shales between the limestone and the granite. The mountains are like huge, bare, brown, downs. Perched on their shoulders are the half-underground villages or douls of the Ossetes, where neither horsemen nor guns can attack them. The vulture soars above, his piercing eve scanning the valley. Here and there are seen the quaint Ossetian tombs with convex, curved roofs, and ledges, along which are placed skulls and horns, as offerings to the manes of mighty hunters, now before the Lord. But of game there is little visible. Multitudes of small raptores hover around, or sit on the telegraph wires. The children in summer wear white wideawake hats, that can be bought for a few pence, and are most excellent head gear. The Ossetes, as one of them told me, who was most anxious that I -should enlist him and some 100 of his tatterdemalions for 
service against the Boers, are the bravest people in the world. And the Russians informed me that the boast was by no means a ridiculous one. From Passanûr to Mléti mountains 9,000 to 10,000 feet high rise above the oak scrub in the valley. Distant views are obtained of the.Siem Brati, or Seven Brothers, whose saw-like edge divides Europe from Asia. At Mléti there is a fine old church. 'The traveller will do well to stop here for the night, for the post-house is warm and fairly clean, whilst the food is passable.

From the windows of the Mléti past-house is obtained the view of the zig-zag ascent shown in the photograph. In the snow-field seen to the observer's right stands the station of Gûdaûr, at a height of 6,800 feet, just on the southern slope of the Aràgua. The "Seven Brothers," clad in eternal white mantles, watch the way. Close here is a little cross of granite. From it, the mountain which marks the great divide or water-parting, takes its name Krestòvaya Gorà, or Mountain of the Cross. Here the road passes its highest point a little over 7,000 feet; climbing skilfully over the col it crosses, but does not cut through the mountain chain. Probably the hosts of Gengis Khân swept over here on their way to ransack Georgia. In the next eight miles the traveller descends 2,000 feet. But the incline, managed by ramps in zig-zag, is nowhere abrupt. The yamschil detaches two horses at Gûdaûr and starts the remaining pair at a gallop. At each rapid turn of the road the chaise seems as if it, with its horses and contents, must be launched into eternity. But not a bit of it! With a sudden turn and no check of speed, the next ramp is entered, and taken at the same wild gallop. After crossing the pass a few times one becomes accustomed to the pace and finds it most exhilarating. But the first time-well, perhaps one is not sorry to pull up in safety at Kobi, in the Terek Valley.

The north wind blows fresh. It is as if grey Europe had sent her cold messenger into Asia. The next post-house is Ziòn.' Thence to Kasbèk the valley opens out and the uncomformable strata assume the most fantastic patterns where the soil reveals them. Suddenly Kasbèk, if the weather be clear, appears in the splendour of its snowcrowned solitary dome. Its ancient names were Mkuinvari the "Ice Mountain," the "White Mountain," and "Christ's Mountain." The Georgians called it Stephans-zminda, St, Stephen's. Kasbèk is simply the corruption of Kasi Bèg, the name of a local chief. Some say Prometheus was bound here. At all events there were plenty of carrion-birds to tear at his liver. An interesting excursion can be made on horseback to the foot of the Devdoràk glacier. Kasbèk is a splendid solitary mountain between 17,000 and 18,000 feet high. It yields in grandeur to Araràt or Fuji, only because of the proximity of other giants.

The military road soon enters the gloomy defile of Dariel, the Portc Sarinatica of the ancients. Four thousand feet high, the rocky portals of Asia frown on Terek's waters, that rush madly to the north. At the north entrance of the defile the Russians have built a loopholed redoubt with castellated walls. Close to it a limestone rock juts into the valley surmounted by a ruined tower. This is the Zàmok Tamàra, or castle of Tamàra, in which a fabled queen of the namo dwelt and took toll of travellers. She was wont, it is said, to cast their bodies into the foaming Terek after she had done with them. This mythically beautiful demon, of whom Lermontòf so sweetly sings, must'not be confounded with the pious Queen Tamàra of Georgia, in 
the XII. Century. The mountains recede and at Lars, Terek winds quietly through a grassy valley, in which stand sentinels of limestone, taking lovely tints in the sunshine. Their summits are 3,000 feet above the waters that almost lave their walls. There is plenty of scrub and cover here, in which the woodcock and wild boar love to dwell. At Lars post-house is a specimen of the Tûr (Capra Caucasica), whose magnificent form is sadly caricatured by the entomologist. This grand mountain goat is finer than the best mouflon that ever wore a curled horn. It will be met with on Kasbèk at an elevation of from 7,000 to 10,000 feet; but is shy and difficult of approach at all times.

From Lars to Balta we galloped with a troika, or three horses harnessed abreast, of which. the outer off-side, amused himself by taking flying leaps over the heaps of road-metal by the wayside. The scencry here, though pleasant, appears tame after the gloomy rocks of Dariel, or the glimpses of the snow mountains through the clouds. A curious feature in the military road is the manner in which avalanches are avoided. It was at first deemed possible to protect the way from these snow-slides by galleries, similar to those constructed on the Canadian Pacific Railway. But these were found insufficient for the purpose. At great expense, therefore, regular tunnels were cut into the sides of the mountains, where the avalanches were most dangerous. Between Kobi and Lars are several of these structures. A regular service of snow-clearers is kept at work in winter. The men employed wear masks or coloured goggles, to ward off snow-blindness. This is a necessary precaution. I found on my first journey across the mountains that I could scarcely see for some time owing to neglect of some similar measures. Vladikàvkas is uninteresting. Here we find the mud, dust, or snow, of Russia, her interminable steppes, not without beauty; the railway; the return to the banality of the plains. 